\title{
Draft Methodology to Specify the Railway Sections Capacity
}

\author{
Borna Abramovic ${ }^{1}$, Vladislav Zitricky ${ }^{2 *}$ and Pavol Mesko ${ }^{2}$ \\ ${ }^{1}$ University of Zagreb, Faculty of Transport and Traffic Sciences, Department of Railway \\ Transport, ZUK Borongaj, Object 70, Borongajska 83A, 10000 Zagreb, Croatia; Email: \\ borna.abramovic@fpz.hr \\ ${ }^{2}$ University of Zilina, Faculty of Operation and Economics of Transport and Communications, \\ Department of Railway Transport, Univerzitna 1, 01026 Zilina, Slovak Republic; Email: \\ vladislav.zitricky@fpedas.uniza.sk,pavol.mesko@fpedas.uniza.sk
}

\section{*Corresponding Author: Vladislav Zitricky}

\begin{abstract}
This paper presents the individual parameters of the selected railway corridors in the selected country. Particularly, it describes the specific features of selected corridors in this country, summarizes their capacity, as well as proposes the methodology in order to specify the capacity of given railway section. The outcome is represented by the calculation of the appropriate railway section capacity implemented on the particular railway corridor in the selected EU country.
\end{abstract}

Keywords: Railway capacity, railway section, methodology, calculation, railway transport

\section{Introduction}

Conception of railway corridors is one element in order to support the objectives of the "White paper 2011 - Roadmap to a Single European Transport Area - Towards a competitive and resource efficient transport system". Establishing the competitive railway market in the European area can allow for strengthening the position of railway transport [1].

Currently, it is possible to notice a growing trend of utilizing road transport. Road transport is especially effective for its flexibility, however the railway sections capacity is its deficiency. The negative effect on the environment, including increasing frequency of congestion, increasing noise and the construction of the road network and land occupation are other important features. Transport safety is closely related to the damage caused when operating road transport. Road safety with advancing is dramatically decreased, due to the increase of traffic accidents [2-4].

Development and support of the automobile industry in the Slovak Republic has synergic effect on use and development of combined transport. The inclusion of track lines from net of Slovak railways has an important purpose in order to ensure the speed and high-quality railway connection among European seaports and intermodal terminals in Slovak Republic. 
General railway operation (passenger and freight) on the railway corridors can cause several issues: construction of the railway traffic diagram (trains path for passenger trains and freight trains), consumption capacity of the track lines or operation issues [5-8].

\section{Specific Features of Selected Corridors in the Selected Country}

Accessing the railway market allows to enter new railway operators to the railway network. In order to optimize the utilization of this network and ensure its reliability, it is inevitable to establish additional procedures for strengthening the cooperation on alignment of international train journeys for freight trains among infrastructure managers [9-11].

The establishing international railway corridors, creating the European railway network for competitive cargo, needs to be performed in a way equivalent with the trans-European Transport Network (TEN-T) and/or the European Railway Traffic Management System (ERTMS) corridors. To that end, the coordinated development of the networks is necessary, and in particular, in regard to the integration of the international corridors for railway cargo into the existing TEN-T and the ERTMS corridors [2,3].

The planned measures to improve the performance and capacity of railway transport should have small impact on users of railway transport. Thus, it is necessary to include all the planned measures to the establishment plan. And also, all planned measures, which should have impact to less capacity of infrastructure, must be regularly published or discussed with the infrastructure managers $[2,3,12]$.

The management of railway corridors should also include procedures for the alignment of the infrastructure capacity for international freight trains performing on such corridors. Those procedures should recognize the necessity for capacity of other types of transport, including passenger transport $[13,14]$.

As for the area of the Slovak Republic, three railway corridors are placed:

- railway corridor RFC 5,

- railway corridor RFC 7,

- railway corridor RFC 9.

\subsection{Features of the Railway Corridor 5}

Railway corridor RFC 5 (Baltic - Adriatic corridor) makes connection between Nord part of Europe (Baltic Sea) and South part of Europe (port of Khoper in Slovenia). Corridor passes cross countries: Poland, Slovak Republic, Austria, Italy and Slovenia. 
On the network of the Slovak railways entry point of corridor, the station Skalité from Poland railway network is considered to be the cross-border station and cross-border station Devínska Nová Ves to Austrian railway network is the exit point. In figure 1, the RFC 5 in the Slovak Republic is showed.

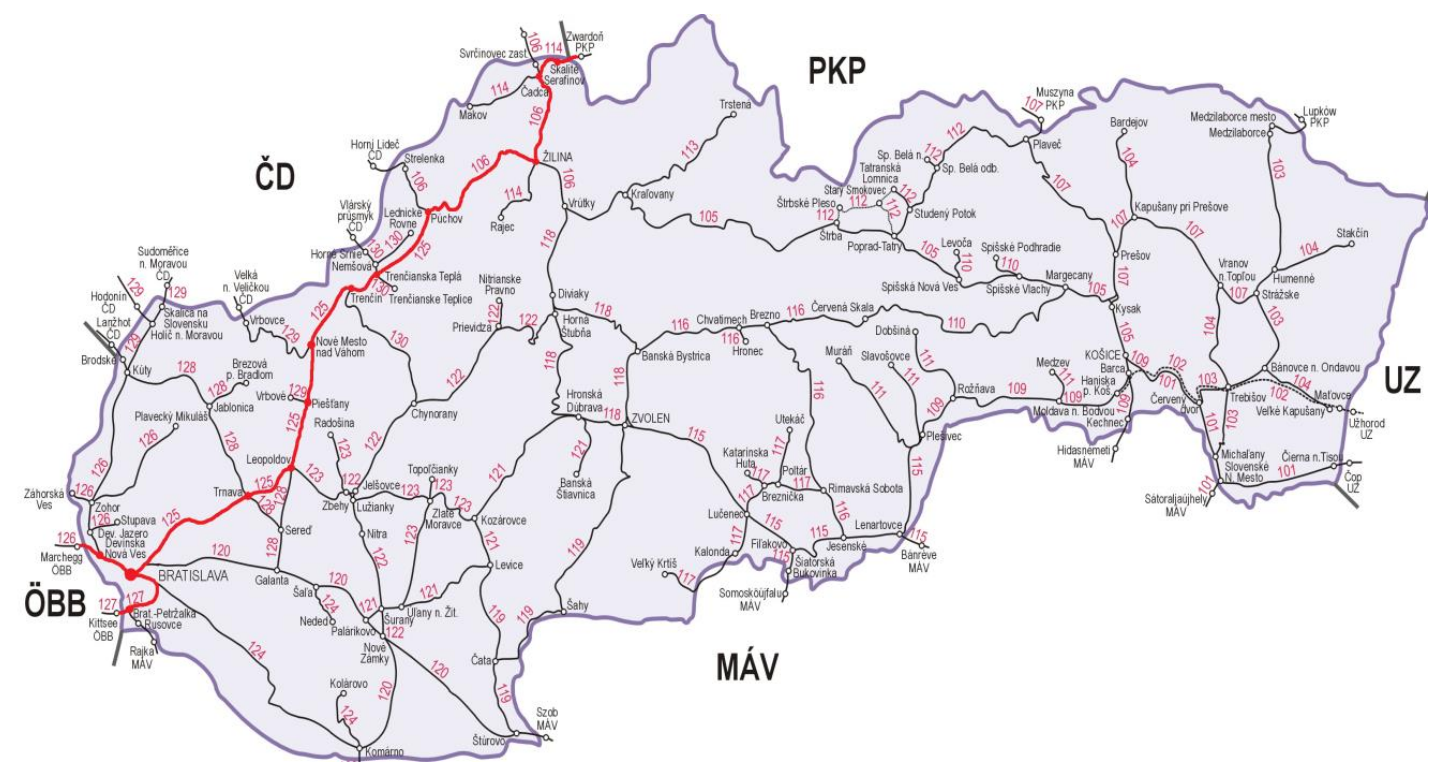

Fig. 1 Railway corridor 5 on the Slovakian railways network. Source: [authors]

In figure 2, an overview of number of trains on the RFC 5 in the Slovak Republic is processed. RFC 5 in the Slovak Republic is double track, without short track section Čadca -Skalité (single track). Operation on the RFC 5 is mixed and consists of passenger and freight transport. According to the Regulation (EU) No 913/2010 [5], this is not an ideal situation. General operation (passenger and freight) on the corridors can cause a large consumption of the railway infrastructure capacity.

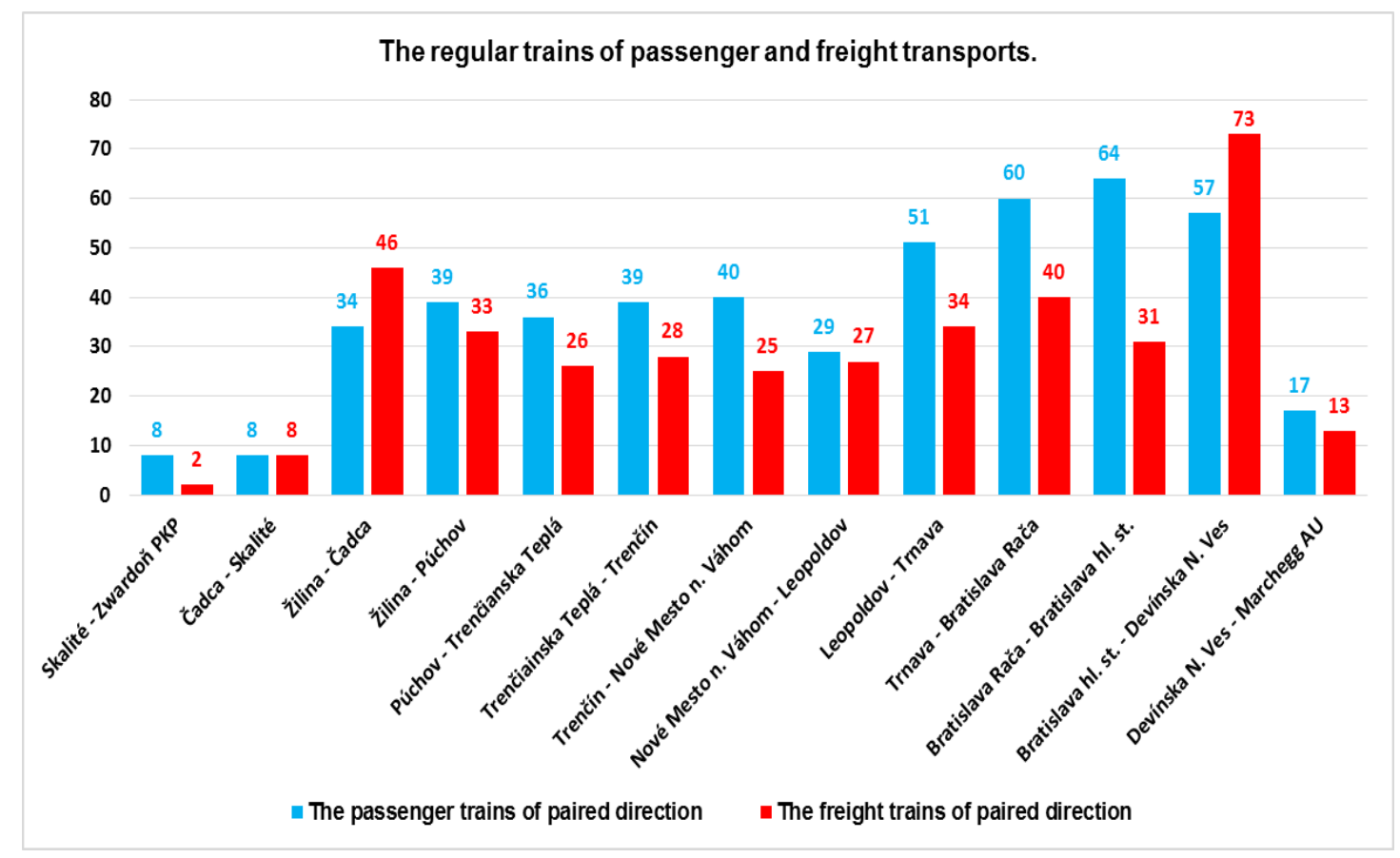

Fig. 2 An overview of regular trains of passenger and freight transport regarding the RFC 5. Source: [authors] 


\subsection{Features of the Railway Corridor 7}

Rail freight corridor 7 connects middle Europe (city of Prague) and east part of Europe (Black sea). Corridor passes through the Czech Republic, Slovak Republic, Hungary, and Romania with a branch via the Bulgaria and Greece.

Cross-border station Kúty Gr. represents the entry point of the RFC 7 on the railways network in the Slovak Republic and cross-border station Štúrovo Gr. is the exit point. Figure 3 illustrates the corridor map of this corridor.

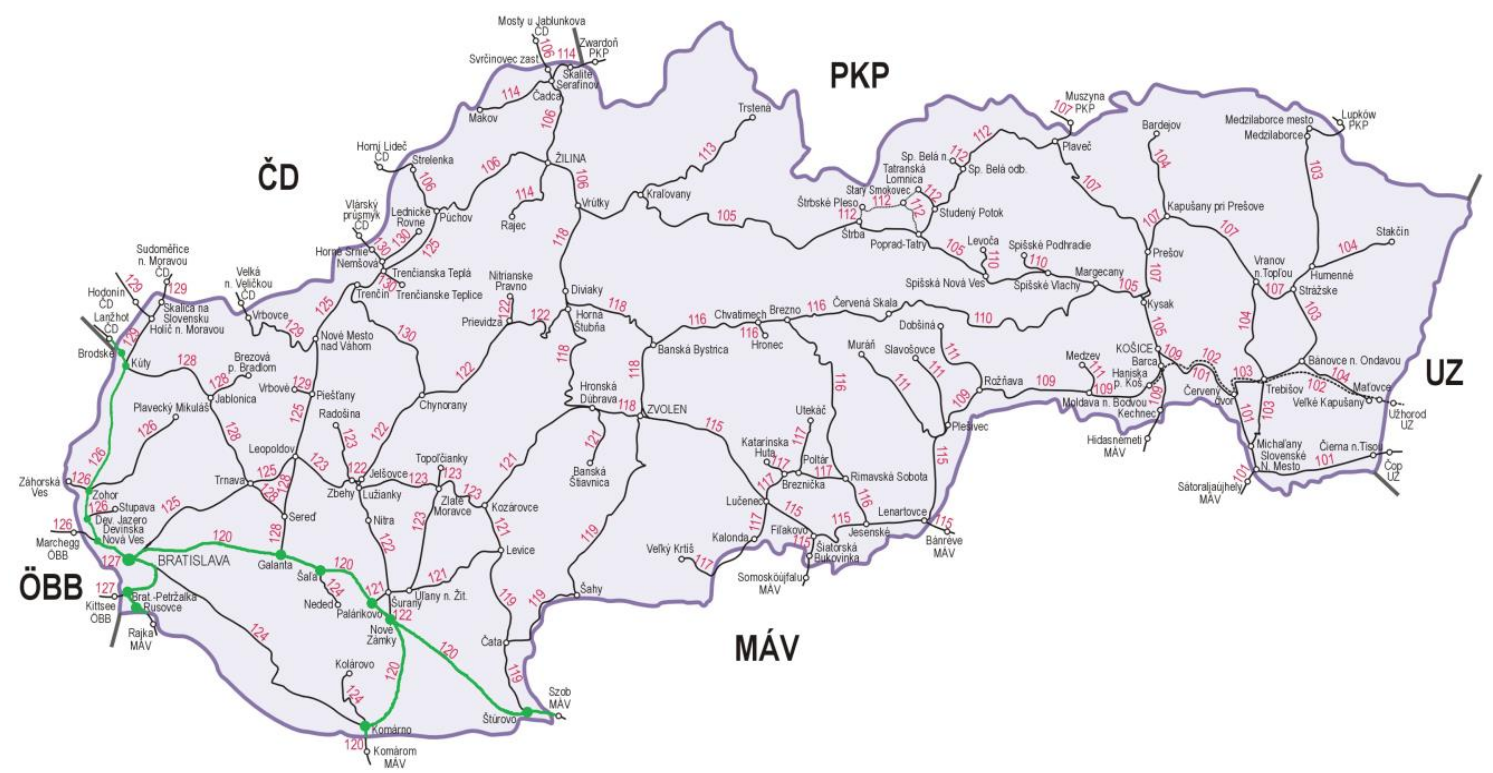

Fig. 3 Railway corridor 7 on the Slovak railways network. Source: [authors]

On the railway corridor 7 in the Slovak Republic, passenger and freight railway operations are common and this railway section is double track. Analysis of transport volume on this corridor is vividly shown in figure 4.

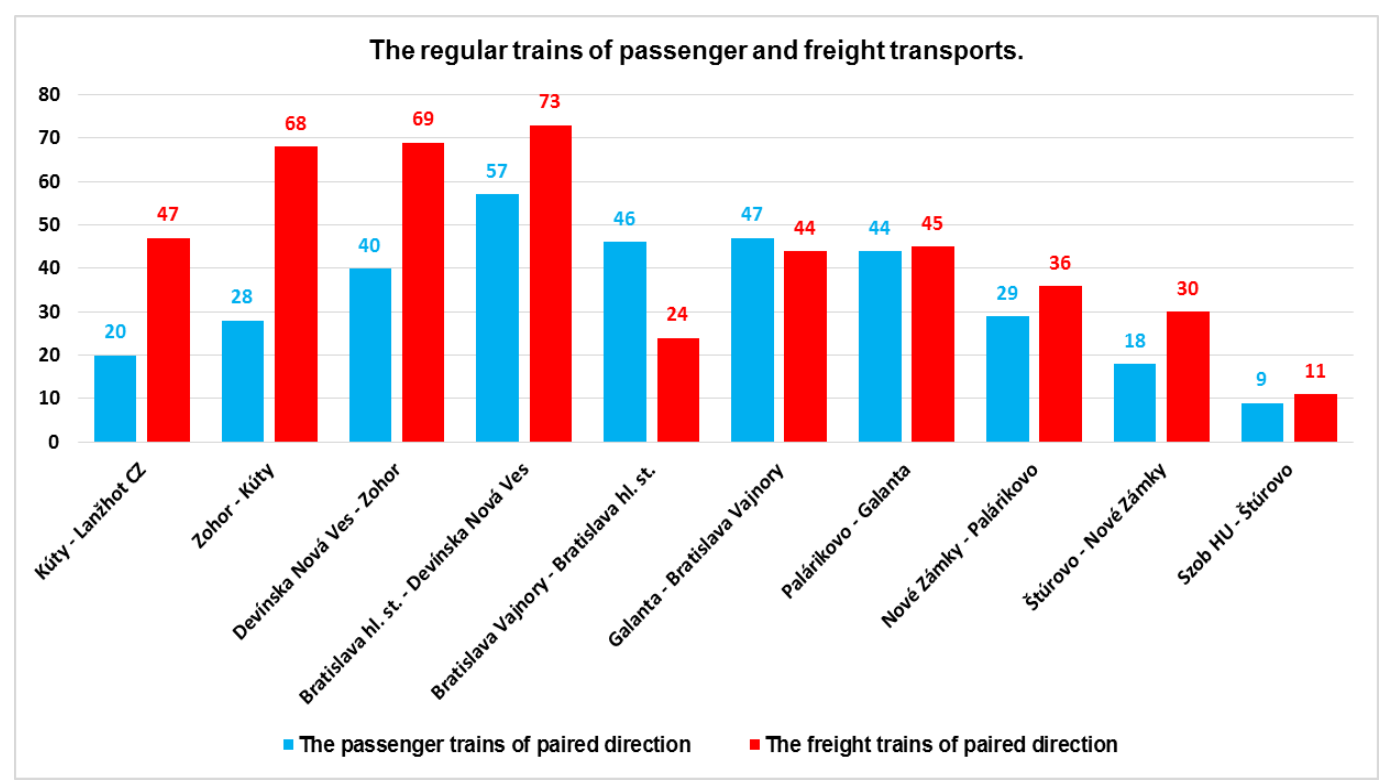

Fig. 4 An overview of regular trains of passenger and freight transport regarding the RFC 7. Source: [authors] 


\subsection{Features of the Railway Corridor 9}

Railway corridor 9 connects the Czech Republic and the Slovak Republic. Cross-border station Čierna nad Tisou is the initial point of this corridor 9 and cross-border station Lúky pod Makytou Gr. is the exit point in the Slovak railways network.

The RFC 9 in the Slovak Republic is illustrated in following figure 5.

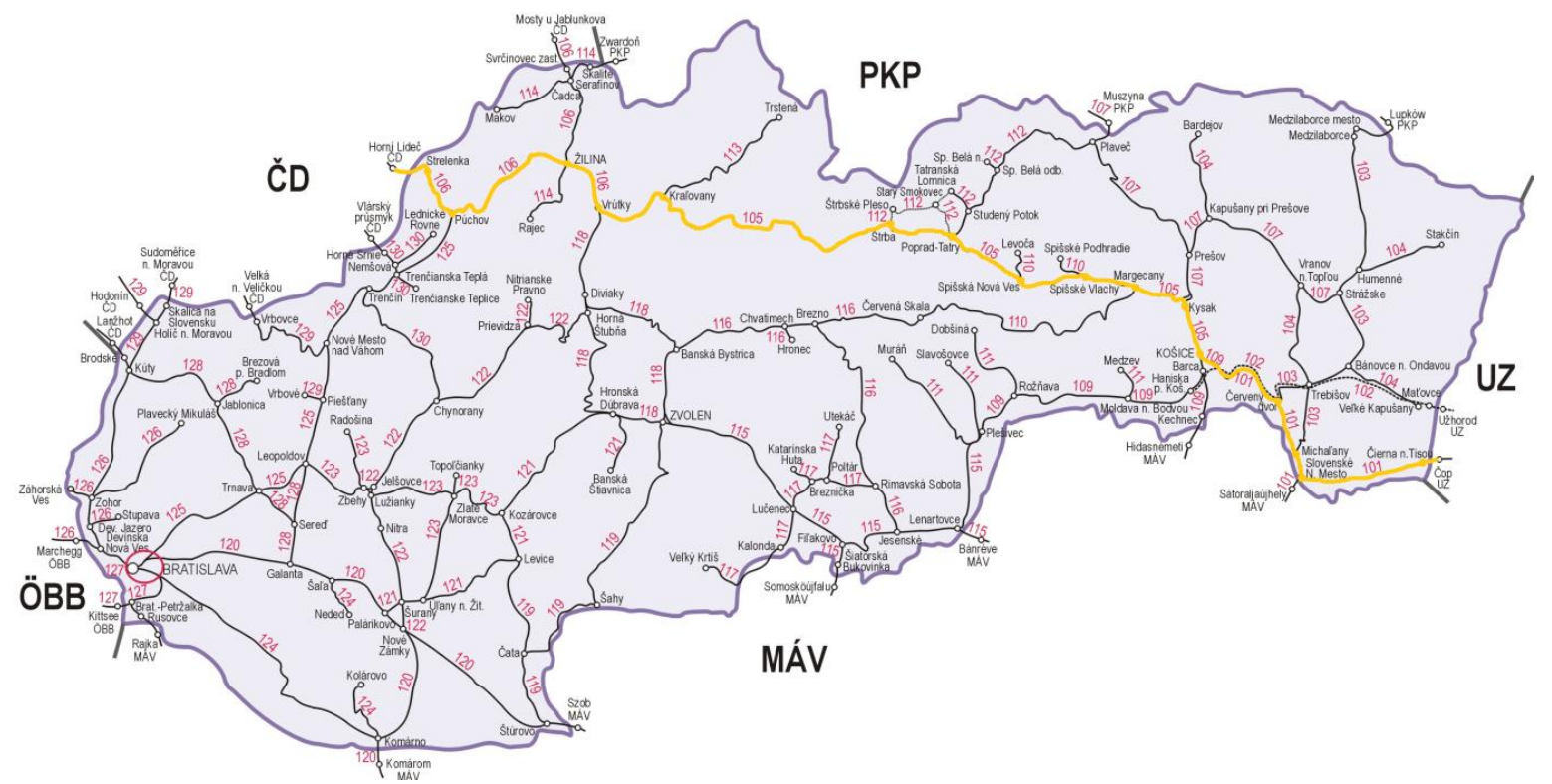

Fig. 5 Railway corridor 9 on the Slovak railways network. Source: [authors]

On this corridor in the Slovak Republic, passenger and freight railway operations are common. An overview of the transport volume in the railway corridor 9 is showed in figure 6 . This corridor is also double track.

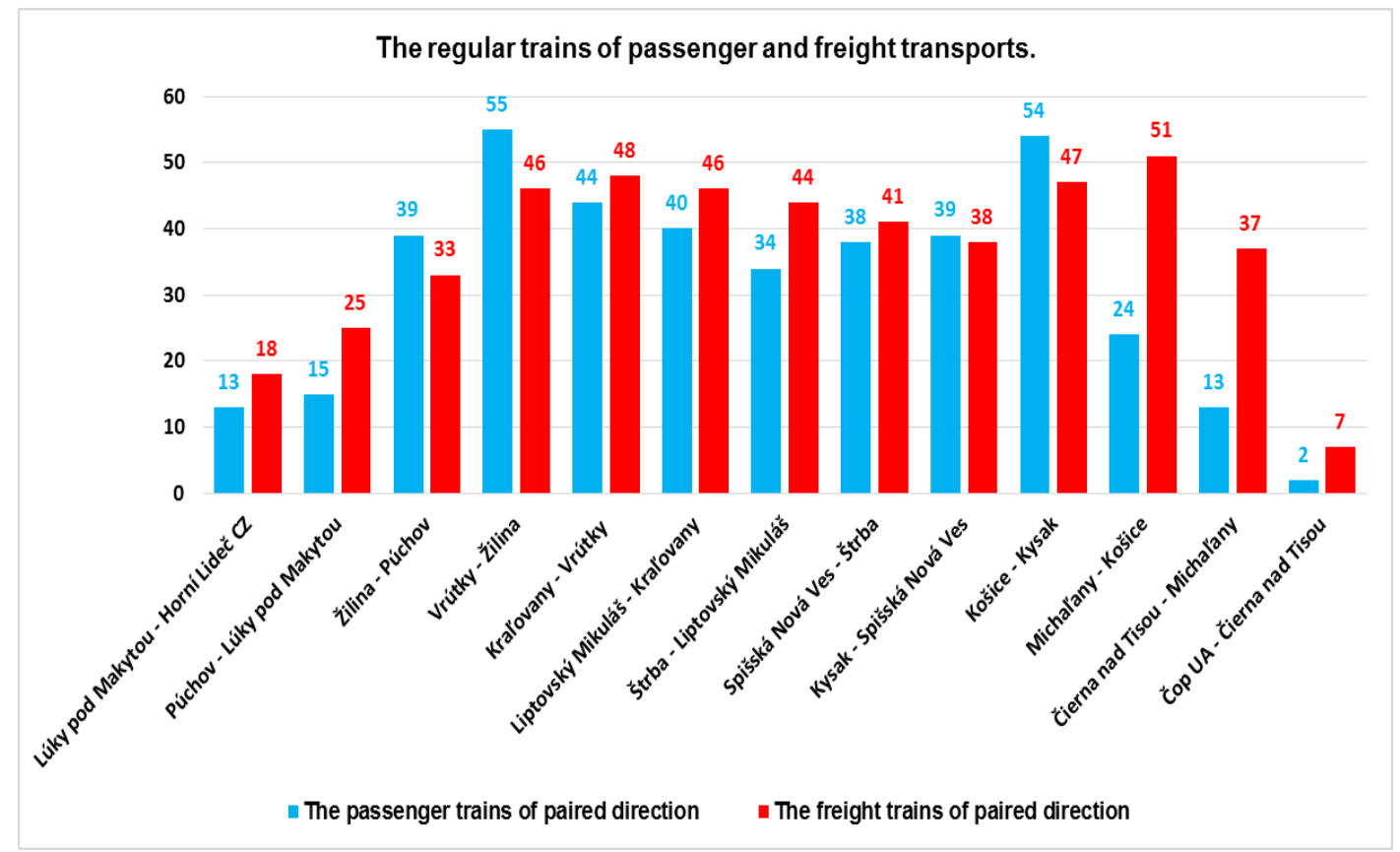

Fig. 6 An overview of regular trains of passenger and freight transport regarding the RFC 9. Source: [authors] 


\section{Data and Methods}

For railway transport, railway section capacity has a lot of definitions, however, the most explicit one is: Railway section capacity is the railway efficiency expressed in number of trains which are operated on particular railway infrastructure without compromised required quality of railway traffic [15-17]. This definition specifies the range of train service with respect to its quality. This firstly emphasizes importance of transport service quality and a fact that transport is executed mostly in stochastic conditions [2].

To specify the railway section capacity, following methods can be utilized $[6,7,9,11,16,17]$ :

- Graphic,

- Analytical,

- Simulation.

For our purpose, in order to calculate the capacity of the railway corridors in the Slovak Republic, the graphic method was used. This method is related to determining the time of the railway section occupation $[2,13,18,19]$.

Draft methodology to specify the railway section capacity was based on the analysis of traffic diagram and consisted from nest steps $[2,13,16,20]$ :

1. calculating the total number of trains,

2. specifying the total time of the railway section occupation,

3. determining the average time of occupation per one train journey,

4. calculating the total buffer time of trains,

5. calculating the railway section capacity.

\section{Obtained Results}

Determining the railway section capacity has a considerable effect on transport operation of railway tracks. Appropriate capacity is important to organize the smooth and safe traffic.

In our case study, specifying the railway section capacity is implemented on individual railway corridors on the Slovak railways network. It is calculated for each railway section separately. For better clarity, it is calculated the coefficient of railway capacity as well [16,21]. The coefficient is determined on the basis of the equation (see Eq. 1):

$$
\mathrm{c}_{\mathrm{cte}}=\mathrm{N} / \mathrm{n} * 100, \quad[\%]
$$

where: $c_{c t e}$ is coefficient of railway capacity [\%], $n$ is the railway section capacity [trains], $N$ denotes the number of trains based on the timetable traffic diagrams [trains]. 
Table 1 summarizes the obtained values of the railway section capacity for the RFC 5. First railway section Skalité - Čadca is only single track section, thus railway capacity value is specified for both directions. The highest consumption of corridor capacity is only approximately $55 \%$.

Table 1 RFC 5 railway section capacity. Source: [authors]

\begin{tabular}{|c|c|c|c|c|c|}
\hline \multirow[b]{2}{*}{ Section } & \multirow{2}{*}{$\begin{array}{l}\text { Limited track } \\
\text { line section }\end{array}$} & \multicolumn{2}{|c|}{ Capacity [trains] } & \multicolumn{2}{|c|}{$\mathrm{c}_{\text {ccte }}[\%]$} \\
\hline & & $\begin{array}{c}\text { Even } \\
\text { direction }\end{array}$ & $\begin{array}{c}\text { Odd } \\
\text { direction }\end{array}$ & $\begin{array}{c}\text { Even } \\
\text { direction }\end{array}$ & $\begin{array}{c}\text { Od } \\
\text { direction }\end{array}$ \\
\hline Skalité - Čadca & Čadca - Skalité & 46 & 77 & \multicolumn{2}{|c|}{20.9} \\
\hline Čadca - Žilina & Čadca - Žilina & 165 & 165 & 36.4 & 37.6 \\
\hline Žilina-Púchov & Žilina - Púchov & 128 & 126 & 49.8 & 48.6 \\
\hline $\begin{array}{l}\text { Púchov- } \\
\text { Bratislava }\end{array}$ & $\begin{array}{c}\text { Trnava - } \\
\text { Bratisalava Rača }\end{array}$ & 192 & 184 & 43.8 & 47.3 \\
\hline $\begin{array}{c}\text { Bratislava- } \\
\text { Devínska Nová Ves }\end{array}$ & $\begin{array}{c}\text { Devínska Nová Ves - } \\
\text { Bratislava }\end{array}$ & 188 & 196 & 54.8 & 55 \\
\hline
\end{tabular}

Resulting values of the railway capacity of the railway corridor 7 are summarized in table 2 . Capacity consumption on the corridor is not so high. The corridor tracks are used only on the 33.3 $\%$ (or $55 \%$ on the section Kúty - Bratislava).

Table 2 RFC 7 railway section capacity. Source: [authors]

\begin{tabular}{c|c|c|c|c|c}
\hline \multirow{2}{*}{ Section } & \multirow{2}{*}{$\begin{array}{c}\text { Limited track } \\
\text { line section }\end{array}$} & \begin{tabular}{c} 
Capacity [trains] \\
Even \\
\cline { 3 - 6 }
\end{tabular} & $\begin{array}{c}\text { Odd } \\
\text { direction } \\
\text { direction }\end{array}$ & $\begin{array}{c}\text { Even } \\
\text { direction }\end{array}$ & $\begin{array}{c}\text { Od } \\
\text { direction }\end{array}$ \\
\hline $\begin{array}{c}\text { Kúty - } \\
\text { Bratislava }\end{array}$ & $\begin{array}{c}\text { Devínska Nová Ves }- \\
\text { Bratislava }\end{array}$ & 188 & 196 & \multicolumn{2}{|c}{54.8} \\
\hline $\begin{array}{c}\text { Bratislava }- \\
\text { Stúrovo }\end{array}$ & $\begin{array}{c}\text { Bratislava - } \\
\text { Bratislava Vajnory }\end{array}$ & 173 & 171 & 35.4 & 33.3 \\
\hline
\end{tabular}

Table 3 includes obtained values of the railway section capacity for the RFC 9. Rail freight corridor 9 is the primary railway track in the Slovak Republic. Given this fact, the capacity consumption on this corridor is low. The highest value of capacity consumption is approx. $50 \%$.

Table 1 RFC 9 railway section capacity. Source: [authors]

\begin{tabular}{c|c|c|c|c|c}
\hline \multirow{2}{*}{ Section } & Limited track & \multicolumn{2}{|c|}{ Capacity [trains] } & \multicolumn{2}{|c}{$\mathbf{c}_{\text {ccte }}$ [\%] } \\
\cline { 3 - 6 } & line section & $\begin{array}{c}\text { Even } \\
\text { direction }\end{array}$ & $\begin{array}{c}\text { Odd } \\
\text { direction }\end{array}$ & $\begin{array}{c}\text { Even } \\
\text { direction }\end{array}$ & $\begin{array}{c}\text { Od } \\
\text { direction }\end{array}$ \\
\hline $\begin{array}{c}\text { Čierna nad Tisou - } \\
\text { Košice }\end{array}$ & $\begin{array}{c}\text { Čierna nad Tisou - } \\
\text { Michal'any }\end{array}$ & 91 & 88 & \multicolumn{2}{|c}{37.4} \\
\hline $\begin{array}{c}\text { Košice - } \\
\text { Kral'ovany }\end{array}$ & Košice - Kysak & 173 & 170 & 49.7 & 50.6 \\
\hline $\begin{array}{c}\text { Kral'ovany - } \\
\text { Púchov }\end{array}$ & Žilina - Púchov & 128 & 126 & 49.8 & 48.6 \\
\hline $\begin{array}{c}\text { Púchov - } \\
\text { Lúky pod Makytou }\end{array}$ & $\begin{array}{c}\text { Púchov - } \\
\text { Lúky pod Makytou }\end{array}$ & 178 & 169 & 17.4 & 16.5 \\
\hline
\end{tabular}




\section{Conclusion}

Results for specifying the railway sections capacity represents the appropriate capacity of railway corridors regarding freight transport, however, passenger and freight trains are operated on individual corridors.

General operation has not great effect to capacity consumption on the railway corridors on the Slovak railways network. In case of transport volume increase, the railway infrastructure has a possibility to ensure the safety and smooth railway operation.

These days, issue consists in the train journeys within the traffic diagram. If the traffic flows, in ideal case, move from road transport to railway transport, the current railway sections capacity will be insufficient.

On the basis of the processed analysis, it can be concluded that the railway sections capacity in the Slovak republic is too low and railway infrastructure do not need the great financial measures regarding the complying the objectives of the Regulation (EU) 913/2010. However, the reconstruction of railway infrastructure in the Slovak Republic is inevitable in order to modernize and create the interoperability in regard to railway market in the European Union.

\section{Acknowledgements}

The paper is supported by the VEGA Agency by the Project 1/0095/16 "Assessment of the quality of connections on the transport network as a tool to enhance the competitiveness of public passenger transport system" that is solved at Faculty of Operations and Economics of Transport and Communication, University of Žilina.

\section{References}

[1] European strategies. (2011). White paper 2011 - Roadmap to a Single European Transport Area - Towards a competitive and resource efficient transport system, from https://ec.europa.eu/transport/themes/strategies/2011_white_paper_en.

[2] Černá, L. \& Mašek, J. (2015). The proposal the methodology of the supply chain management in transport and logistic company. Transport means 2015: proceedings of the 19th international scientific conference, Kaunas University of Technology, Lithuania. ISSN 1822296X.

[3] Nedeliakova, E., Sekulova, J. \& Nedeliak, I. (2014). Risk management in the conditions of railway infrastructure manager. Ekonomicko-manazerske spectrum, 8(1), 22-28. ISSN 13370839 . 
[4] Sun, W. (2016). Study on calculation method for carrying capacity of main railway line based on transportation demand. Journal of the China Railway Society, 38(12), 8-13. DOI: 10.3969/j.issn.1001-8360.2016.12.002.

[5] Regulation (EU) No. 913/2010 of the European parliament and of the council - concerning a European rail network for competitive freight is one possibility to increase of transport $\begin{array}{lllll}\text { volume } & \text { in } & \text { railway } & \text { transport, } & \text { from }\end{array}$ lex.europa.eu/LexUriServ/LexUriServ.do?uri=OJ:L:2010:276:0022:0032:en:PDF.

[6] Li, H., Luan, X., Meng, L. \& Wang, Y. (2014). Calculation method for released capacity of existing railway. China Railway Science, 35(3), 113-119. DOI: 10.3969/j.issn.10014632.2014.03.18.

[7] Jiamin, Z. \& Baoming, H. (2011). Analysis and calculation of the scheduled waiting time for the train route. Proceedings - 4th International Conference on Intelligent Computation Technology and Automation, ICICTA 2011, 1(2011), 54-58.

[8] Morlok, E.K. \& Chang, D.J. (2004). Measuring capacity flexibility of a transportation system. Transportation Research Part A: Policy and Practice, 38(6), 405-420. DOI: 10.1016/j.tra.2004.03.001.

[9] Zhang, J.-M. \& Han, B.-M. (2011). Optimization on the occupation order for trains on tracks of the railway station. Journal of Transportation Systems Engineering and Information Technology, 11(3), 100-107.

[10] Luo, Y.-J., Liu, J., Sun, X. \& Lai, Q.-Y. (2015). Regression model for daily passenger volume of high-speed railway line under capacity constraint. Journal of Central South University, 22(9), 3666-3676. DOI: 10.1007/s11771-015-2908-9.

[11] Zhang, H.-B. \& Dong, B.-T. (2011). Railway timetable saturation based on capacity calculation. Journal of Transportation Systems Engineering and Information Technology, 11(4), 129-134.

[12] Yaghini, M., Sarmadi, M., Nikoo, N. \& Momeni, M. (2014). Capacity Consumption Analysis Using Heuristic Solution Method for Under Construction Railway Routes. Networks and Spatial Economics, 14(3-4), 317-333. DOI: 10.1007/s11067-014-9223-0.

[13] Simon, B. \& Endemann, P. (2016). Corridor Development from a Regional Perspective: The Case of the Frankfurt/Rhine-Main Region. Contributions to Economics, 207, 81-97. DOI: 10.1007/978-3-319-15708-5-5. 
[14] Zhang, H., Dong, B. \& Sun, Y. (2016). Multi-type empty car dynamic distribution method based on capacity constraints. Journal of Beijing Jiaotong University, 40(6), 50-56. DOI: 10.11860/j.issn.1673-0291.2016.06.009.

[15] Chen, L., Li, X. \& Liu, G. (2013). Analysis of the capacity of the turning-back station in the railway system. ICTE 2013 - Proceedings of the 4th International Conference on Transportation Engineering, 2761-2765. DOI: 10.1061/9780784413159.401.

[16] Lindfeldt, O. (2011). An analysis of double-track railway line capacity. Transportation Planning and Technology, 34(4), 301-322. DOI: 10.1080/03081060.2011.577150.

[17] Zheng, Y.-J., Zhang, X.-C., Xu, B. \& Wang, L.-L. (2011). Carrying capacity reliability of railway networks. Journal of Transportation Systems Engineering and Information Technology, 11(4), 16-21.

[18] Tian, R. \& Qu, M. (2013). Contradiction analysis and freight capacity promotion measures of mixed passenger and freight transportation during the spring festival. ICTE 2013 Proceedings of the 4th International Conference on Transportation Engineering, 1538-1544. DOI: $10.1061 / 9780784413159.223$.

[19] Ni, S., Zuo, D., Lv, H. \& Yin, Y. (2011). The carrying capacity of high speed railway under the mode of high and medium speed mixture trains in one line. ICTE 2011 - Proceedings of the 3rd International Conference on Transportation Engineering 2011, 1245-1250. DOI: $10.1061 / 41184(419) 206$.

[20] Francesco, R., Gabriele, M. \& Stefano, R. (2016). Complex railway systems: capacity and utilisation of interconnected networks. European Transport Research Review, 8(4), Article number 29. DOI: 10.1007/s12544-016-0216-6.

[21] Markovic, I., Vucic, D. \& Muic, M. (2004). Railway line "Zagreb-Rijeka". Promet - Traffic Traffico, 16(2), 83-89. 